\title{
Dermatology
}

\section{Relationship between the CAG Repeat Polymorphism in the Androgen Receptor Gene and Acne in the Han Ethnic Group}

\author{
Zhi Yang ${ }^{a}$ Haijing Yu ${ }^{b}$ Baowen Cheng ${ }^{b}$ Wenru Tang ${ }^{b}$ Yongli Dong ${ }^{b}$ \\ Chunjie Xiao $^{b}$ Li He $^{a}$ \\ ${ }^{\mathrm{a}}$ Department of Dermatology, First Affiliated Hospital of Kunming Medical College, and ${ }^{\mathrm{b}}$ Key Laboratory of \\ Bioresources Conservation and Utilization and Human Genetics Center of Yunnan University, Kunming, Yunnan, \\ PR China
}

\section{Key Words}

Acne vulgaris - Androgen receptor $\cdot$ CAG repeat polymorphism

\begin{abstract}
Background: The modulatory domain of the human androgen receptor (AR) gene contains a polymorphic CAG repeat coding for a polyglutamine tract which is inversely correlated with transcriptional activity of the AR. Androgens acting through the AR play a crucial role in the pathogenesis of acne vulgaris. We therefore investigated the relationship between CAG repeat polymorphism in the $A R$ gene and acne susceptibility. Methods: 206 acne patients and 200 controls participated in the study. Genomic DNA was extracted from peripheral blood lymphocytes of individual patients, and the CAG repeat region was amplified by polymerase chain reaction (PCR) using fluorescence-labeled primers. Samples were then run on an $A B I 377$ gene scan analysis gel with an internal molecular-weight marker. Ten male samples were chosen randomly for sequencing to confirm the number of CAG repeats. The 2-sample independent $t$ test was used to analyze the data. Results: The mean number of the CAG repeat in the AR was 22.07 (14-28) in the controls and 20.61 (13-26) in the male acne group. There was a significant correlation between the CAG repeat length and male acne. No
\end{abstract}

significant difference was observed between female patients and their controls. Conclusion: The results suggest that the $A R$ gene CAG repeat polymorphism may be one of the candidate genetic markers for male acne susceptibility in the Han population.

Copyright $\odot 2009$ S. Karger AG, Basel

\section{Introduction}

Acne vulgaris is one of the most common skin diseases. An analysis of the 1996 census data in the USA indicated that the prevalence of acne in the age group from 12 to 24 years was $85 \%$ [1]. The role of androgens in the pathogenesis of acne vulgaris is well established [2]. Their effects are mediated by binding to nuclear androgen receptors (ARs) which are localized in the basal layer of the sebaceous gland and outer root $[3,4]$. In a previous study, Imperato-McGinley et al. [5] found that androgen-insensitive subjects who lack functional ARs do not produce sebum and do not develop acne, which suggested that ARs play a key role in the etiology of acne. However, the exact genetic mechanisms how ARs affect acne development are still unclear.

The $A R$ gene resides on chromosome $\mathrm{X}$ and encodes a protein of 910 amino acids [6]. Androgens, when bound

\section{KARGER}

Fax +41613061234 E-Mail karger@karger.ch www.karger.com (c) 2009 S. Karger AG, Basel

$1018-8665 / 09 / 2184-0302 \$ 26.00 / 0$

Accessible online at:

www.karger.com/drm
Dr. Li He

Department of Dermatology

First Affiliated Hospital of Kunming Medical College

Kunming, Yunnan 650032 (PR China)

Tel./Fax +86 871532 9399, E-Mail heli2662@163.com 
to the hormone-binding domain, activate the receptor, causing nuclear translocation of the ligand-receptor complex and a series of molecular events leading to the transactivation of androgen-regulated genes [7]. The $5^{\prime}$-end of exon 1 of the $A R$ gene includes a polymorphic CAG triplet repeat that codes for a polyglutamine tract. Polyglutamine tracts are often present in transcription factors, including SP1 and TATA-binding protein. They are suggested to form polar zippers, which bind specific transcription factors together by hydrogen bonds [8]. The number of the polyglutamine tract is inversely correlated with transcriptional activity of the AR $[7,9,10]$. In addition to the pathological CAG repeat expansions in spinal bulbar muscular atrophy [11], an association between the number of CAG repeats and the risk of prostate cancer was proposed, though not all studies have confirmed the association $[12,13]$.

Moreover, the androgens also play an important role in the development of acne. In the present study, we investigated whether there is an association between acne and the AR CAG repeat polymorphism.

\section{Subjects and Methods}

\section{Subjects}

A total of 406 individuals from the Han ethnic group in China participated in the study; 206 of them were patients presenting with acne including 120 males and 86 females, and 200 including 132 males and 68 females were healthy people used as control group. The control group was matched in age with the case group. All participants in the study signed an informed consent, and human sample handling was approved by Kunming Medical College and Yunnan University.

All subjects were examined in our outpatient unit by dermatologists. Patients with acne venenata and acne cosmetica were excluded from the study. The clinical grade of acne was assessed based on the Consensus Conference on Acne Classification [14]. According to these criteria, mild acne is defined by the presence of comedones, without significant inflammation and a few or no papules, moderate acne by the presence of comedones, with marked inflammatory papules and pustules, and severe acne by the presence of inflammatory nodules, in addition to comedones, papules and pustules. For analysis convenience, patients were divided into two categories, namely mild + moderate and severe acne. Statistical evaluation was performed based on these two groups.

\section{Polymorphism Detection and Statistical Analysis}

Genomic DNA was extracted from peripheral blood of all patients and controls by the phenol-chloroform method according to Gross-Bellard et al. [15].

The AR exon 1 CAG trinucleotide repeat was PCR amplified using primer sequences which were designed by primer 5.0 software with inclusion of a 5'-FAM-labeled forward primer to gener- ate a fluorescent product as follows: forward primer $5^{\prime}$-FAM AGT TAG GGC TGG GAA GGG TC-3' and reverse primer 5'-TAC GAT GGG CTT GGG GAG A-3'. PCR was carried out in a $25-\mu 1$ reaction volume containing 50-100 ng of template DNA, 1.5-2.0 $\mathrm{mM} \mathrm{MgCl}_{2}, 200 \mathrm{mM}$ dNTPs and 15 pmol of each primer, $1 \times$ standard buffer and 2 units of Ampli Taq Gold DNA polymerase (Perkin Elmer, Warrington, UK). PCR amplification was performed on a Perkin Elmer DNA Thermal Cycler. Thermocycling consisted of an initial denaturation of $5 \mathrm{~min}$ at $94^{\circ} \mathrm{C}, 25$ cycles of $1 \mathrm{~min}$ of denaturation at $94^{\circ} \mathrm{C}, 45 \mathrm{~s}$ of annealing at $64^{\circ} \mathrm{C}$ and $45 \mathrm{~s}$ of extension at $72^{\circ} \mathrm{C}$, and a final extension of $7 \mathrm{~min}$ at $72^{\circ} \mathrm{C}$. Appropriate amounts of PCR products $(0.75 \mu \mathrm{l})$ were mixed with $1.75 \mu \mathrm{l}$ of a premixed buffer solution (formamide:loading buffer:standard = 5:1:1). Genescan-350 TAMRA (6-carboxy-tetramethylrhodamine red; Applied Biosystems, USA) was used as the reference standard. Electrophoresis was performed using a $6 \%$ denaturing polyacrylamide gel and an ABI Prism 377 DNA sequencer. The sizes of the CAG-containing DNA fragments were measured using Genescan Analysis 3.0 software (Applied Biosystems). The CAG repeat number of each allele was calculated by function [ $\mathrm{n}=$ (fragment of amplification - 228)/3].

Ten male samples were chosen randomly for sequencing to confirm the number of CAG repeats; primer sequences without labeled fluorescence were designed referring to the former. PCR products were purified by the Wizard Purification Kit (Promega), then directly sequenced in both directions using the Bigdye Terminator v3.1 Cycle Sequencing Kit (Applied Biosystems) according to the standard protocol. The sequences were aligned using the DNAstar software.

Statistical analysis was performed using the statistical package SPSS for Windows (version 11.5, SPSS Inc., Chicago, Ill., USA). The 2-independent-sample t test was used to evaluate the significance of the difference of the number of CAG repeats between the normal control and acne group. Statistical significance was defined as a 2 -side $p$ value of $<0.05$.

\section{Results}

In the Chinese Han males we investigated, the number of $A R$ gene CAG ranged from 14 to 28 among the controls and 13 to 26 among the cases. The numbers of CAG repeats of 10 male samples were confirmed by sequencing as well as by gene scan (fig. 1). The mean CAG repeat length was $22.07(\mathrm{SD}=3.026)$ in the control group, and $20.61(\mathrm{SD}=2.423)$ in the patients. The differences in CAG repeat length between the two groups were statistically significant $(\mathrm{p}<0.001)$. Additionally, when we divided the male patients into two subgroups, i.e. moderate-acne subgroup (mean $=20.79, \mathrm{SD}=2.434$ ) and severe-acne subgroup (mean $=20.50, \mathrm{SD}=2.427$ ), we also found that the CAG repeat length of both subgroups was significantly different from that of the controls $(\mathrm{p}=0.014, \mathrm{p}<0.001$; table 1). The mean CAG repeat length in the female acne group was $21.09(\mathrm{SD}=2.810)$ with a range of $13-30$, while, 


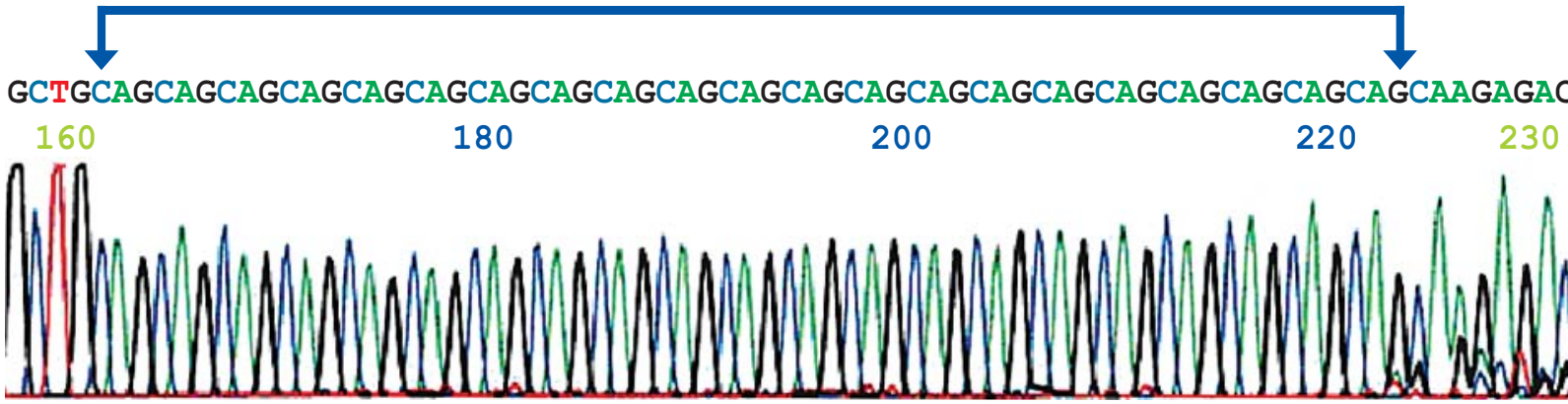

Fig. 1. Gene sequencing of the (CAG)n androgen receptor gene with a polymorphic sequence of 21-repeat length.

Table 1. Comparison of CAG repeat numbers between control and case male subjects

\begin{tabular}{lrrllr}
\hline Group & Number & Mean & $\begin{array}{l}\text { Standard } \\
\text { deviation }\end{array}$ & $\begin{array}{l}\mathrm{F} \\
\text { value }\end{array}$ & $\begin{array}{l}\mathrm{p} \\
\text { value }\end{array}$ \\
\hline Control & 132 & 22.07 & 3.026 & & \\
Acne & 120 & 20.61 & 2.423 & 4.252 & $<0.001$ \\
$\quad$ Mild + moderate & 42 & 20.79 & 2.434 & 2.484 & 0.014 \\
$\quad$ Severe & 78 & 20.50 & 2.427 & 4.108 & $<0.001$ \\
\hline
\end{tabular}

in the female control group, the mean CAG repeat number was $21.32(\mathrm{SD}=3.302)$ with a range of $12-28$. There was no significant difference in the mean number of CAG repeat length among the two groups in women. Furthermore, neither did we find a difference between female patient groups and the control group when the mild-, moderate- and severe-acne subgroups were considered separately (table 2).

\section{Discussion}

There has previously been some evidence that acne is an inherited disease $[16,17]$. The detailed mode of inheritance remains unproven; however, it is most likely polygenic, and genetic factors, Propionibacterium acnes infection, production of inflammation and environmental influences are involved in the etiology of acne [2]. Few acne candidate genes have been proposed, such as human cytochrome P450 1A1 gene [18], steroid 21-hydroxylase gene [19], epithelial mucin gene [20] and CYP17 [21]. Giv-
Table 2. Comparison of CAG repeat numbers between control and case female subjects

\begin{tabular}{llllll}
\hline Group & Number & Mean & $\begin{array}{l}\text { Standard } \\
\text { deviation }\end{array}$ & $\begin{array}{l}\mathrm{F} \\
\text { value }\end{array}$ & $\begin{array}{l}\mathrm{p} \\
\text { value }\end{array}$ \\
\hline Control & 68 & 21.32 & 3.302 & & \\
Acne & 86 & 21.09 & 2.810 & 0.667 & 0.505 \\
$\quad$ Mild + moderate & 59 & 21.07 & 2.878 & 0.646 & 0.519 \\
$\quad$ Severe & 27 & 21.14 & 2.679 & 0.372 & 0.710 \\
\hline
\end{tabular}

en the role of androgen in the pathogenesis of acne, the gene encoding the AR has been an important candidate for the determination of acne risk. However, only one study on CAG repeats among acne patients was reported. In 1998, Sawaya and Shalita [22] found that the AR polymorphism of CAG trinucleotide repeat length exhibited a correlation with some androgenic skin disease but not with acne in Caucasians. Since significant ethnic differences have been observed within the normal range of $A R$ polyglutamine stretch, this means the CAG repeat number of the AR may reflect the variance on genetic background in different races. So it is interesting to study the relationship between the CAG repeat polymorphism of the AR and acne.

In the present study, we evaluated whether the CAG repeat polymorphism in the AR may contribute to acne risk in the Chinese Han ethnic group by a case-control analysis. We observed a significant relationship between the CAG repeat length and male acne risk. A smaller mean number of CAG repeats in the male patients (20.61 \pm 2.423 ) was observed, suggesting that shorter CAG re- 
peat alleles could have a dangerous effect for male acne development. However, in female individuals with severe acne, we did not find a similar association. To our knowledge, this is the first study to investigate the role of the AR CAG repeat polymorphism in the Han ethnic group for acne. Our results were not consistent with the report of Sawaya and Shalita [22] that no association was found between CAG repeat length and acne in Caucasians. One possible explanation is that such a difference may reflect the genetic differentiation between Caucasians and the Han ethnic group.

Our observation of a possible correlation between shorter CAG repeats and male acne is consistent with the association between CAG repeat number and the risk of prostate cancer. The androgen testosterone and its metabolite dihydrotestosterone exert their effects on gene expression and thus affect the sebaceous gland via the AR [23]. In vitro studies show that AR transcriptional activity is influenced by the CAG repeat length, and the length of the CAG tract is inversely correlated with transcriptional activity of the AR [24]. Although the probable increase in AR intrinsic activity with each reduction in AR CAG length is relatively small, these effects are genetically determined and therefore exert effects over a person's entire lifetime. Small changes can therefore have significant cumulative pathological effects over time [25]. Collectively, the evidence supports the hypothesis that the glutamine repeat plays a role in AR function by fine-tuning the balance between excess and deficient receptor function.

However, in female individuals we did not find a similar phenomenon. In addition, there is a difference of 0.65 (male 22.07 vs. female 21.32) in the average number of CAG repeats between male and female controls who have no acne. This result indicated that a lower number of CAG repeats, which may be associated with acne in males, did not have the same level of effect in females. Physiological interplay between androgens and estrogens in various endocrine targets is well established [26]. Each respective hormone may affect the expression of the other's receptor, i.e. androgens of the estrogen receptor and vice versa $[27,28]$, so we speculated that the proportion of ARs and estrogen receptors played an important role in the pathogenesis of female acne, which needs further study. Nevertheless, the etiology of acne is multifactorial, and a few genes are related to the condition. Beyond genetic factors, the environmental factors also deserve investigation to understand female as well as male acne. Further study on interactions between such genes and environmental factors would shed light on the possible genetic mechanisms of acne.

In conclusion, the results of our study suggest that the $A R$ gene CAG microsatellite polymorphism may be one of the candidate genetic markers responsible for male acne in the Han population, and further study of other possible genetic markers with regard to acne will provide new information on the genetic background underlying acne. As well, the complex interaction between the expressions of these genetic loci along with the influence of environmental factors may explain the phenomenon.

\section{Acknowledgements}

This work was supported by the National Natural Science Foundation of China (project No. 30269001, 2003C0001P) and the Key Programme for Science and Technology Development of China (project No. 2004BA901A07, 2004GP09).

\section{References}

1 White GM: Recent findings in the epidemiologic evidence, classification, and subtypes of acne vulgaris. J Am Acad Dermatol 1998; 39:S34-S37.

$\checkmark 2$ Zouboulis CC, Eady A, Philpott M, Goldsmith LA, Orfanos C, Cunliffe WC, Rosenfield R: What is the pathogenesis of acne? Exp Dermatol 2005; 14:143-152.

- 3 Liang T, Hoyer S, Yu R, Soltani K, Lorincz AL, Hiipakka RA, Liao S: Immunocytochemical localization of androgen receptors in human skin using monoclonal antibodies against the androgen receptor. J Invest Dermatol 1993;100:663-666.
-4 Choudhry R, Hodgins MB, Van der Kwast TH, Brinkmann AO, Boersma WJ: Localization of androgen receptors in human skin by immunohistochemistry: implications for the hormonal regulation of hair growth, sebaceous glands and sweat glands. J Endocrinol 1992;133:467-475.

5 Imperato-McGinley J, Gautier T, Cai LQ, Yee B, Epstein J, Pochi P: The androgen control of sebum production: studies of subjects with dihydrotestosterone deficiency and complete androgen insensitivity. J Clin Endocrinol Metab 1993;76:524-528.
-6 Quigley CA, De Bellis A, Marschke KB, el-Awady MK, Wilson EM, French FS: Androgen receptor defects: historical, clinical, and molecular perspectives. Endocr Rev 1995;16:271-321.

7 Chamberlain NL, Driver ED, Miesfeld RL: The length and location of CAG trinucleotide repeats in the androgen receptor $\mathrm{N}$-terminal domain affect transactivation function. Nucleic Acids Res 1994;22:3181-3186.

-8 Rubinsztein DC, Leggo J, Coetzee GA, Irvine RA, Buckley M, Ferguson-Smith MA: Sequence variation and size ranges of CAG repeats in the Machado-Joseph disease, spinocerebellar ataxia type 1 and androgen receptor genes. Hum Mol Genet 1995;4:15851590. 
-9 Choong CS, Kemppainen JA, Zhou ZX, Wilson EM: Reduced androgen receptor gene expression with first exon CAG repeat expansion. Mol Endocrinol 1996;10:15271535.

10 Kazemi-Esfarjani P, Trifiro MA, Pinsky L: Evidence for a repressive function of the long polyglutamine tract in the human androgen receptor: possible pathogenetic relevance for the (CAG)n-expanded neuronopathies. Hum Mol Genet 1995;4:523-527.

-11 Igarashi S, Tanno Y, Onodera O, Yamazaki M, Sato S, Ishikawa A, Miyatani N, Nagashima M, Ishikawa Y, Sahashi K, et al: Strong correlation between the number of CAG repeats in androgen receptor genes and the clinical onset of features of spinal and bulbar muscular atrophy. Neurology 1992;42:23002302.

-12 Stanford JL, Just JJ, Gibbs M, Wicklund KG, Neal CL, Blumenstein BA, Ostrander EA: Polymorphic repeats in the androgen receptor gene: molecular markers of prostate cancer risk. Cancer Res 1997;57:1194-1198.

$>13$ Linja MJ, Visakorpi T: Alterations of androgen receptor in prostate cancer. J Steroid Biochem Mol Biol 2004;92:255-264.

14 Pochi PE, Shalita AR, Strauss JS, Webster SB: Report of the Consensus Conference on Acne Classification. J Am Acad Dermatol 1991;24:495-500.
15 Gross-Bellard M, Oudet P, Chambon P: Isolation of high molecular weight DNA from mammalian cell. Eur J Biochem 1973;36:3238.

16 Herane MI, Ando I: Acne in infancy and acne genetics. Dermatology 2003;206:2428

17 Ballanger F, Baudry P, N'Guyen JM, Khammari A, Dreno B: Heredity: a prognostic factor for acne. Dermatology 2006;212:145149.

18 Paraskevaidis A, Drakoulis N, Roots I, Orfanos CE, Zouboulis CC: Polymorphisms in the human cytochrome P-450 1A1 gene (CYP1A1) as a factor for developing acne. Dermatology 1998;196:171-175.

19 Ostlere LS, Rumsby G, Holownia P, Jacobs HS, Rustin MH, Honour JW: Carrier status for steroid 21-hydroxylase deficiency is only one factor in the variable phenotype of acne. Clin Endocrinol (Oxf) 1998;48:209-215.

20 Ando I, Kukita A, Soma G, Hino H: A large number of tandem repeats in the polymorphic epithelial mucin gene is associated with severe acne. J Dermatol 1998;25:150-152.

-21 He L, Yang Z, Yu H, Cheng B, Tang W, Dong Y, Xiao C: The relationship between CYP17 $-34 \mathrm{~T} / \mathrm{C}$ polymorphism and acne in Chinese subjects revealed by sequencing. Dermatology 2006;212:338-342.

-22 Sawaya ME, Shalita AR: Androgen receptor polymorphisms (CAG repeat lengths) in androgenetic alopecia, hirsutism, and acne. J Cutan Med Surg 1998;3:9-15.
23 Zitzmann M, Nieschlag E: The CAG repeat polymorphism within the androgen receptor gene and maleness. Int J Androl 2003;26: 76-83.

24 Mhatre AN, Trifiro MA, Kaufman M, Kazemi-Esfarjani P, Figlewicz D, Rouleau G, Pinsky L: Reduced transcriptional regulatory competence of the androgen receptor in $\mathrm{X}$-linked spinal and bulbar muscular atrophy. Nat Genet 1993;5:184-188.

$>25$ Mifsud A, Sim CK, Boettger-Tong H, Moreira S, Lamb DJ, Lipshultz LI, Yong EL: Trinucleotide (CAG) repeat polymorphisms in the androgen receptor gene: molecular markers of risk for male infertility. Fertil Steril 2001; 75:275-281.

26 Kreitmann B, Bayard F: Androgen interaction with the oestrogen receptor in human tissues. J Steroid Biochem 1979;11:15891595.

$\checkmark 27$ Adesanya-Famuyiwa OO, Zhou J, Wu G, Bondy C: Localization and sex steroid regulation of androgen receptor gene expression in rhesus monkey uterus. Obstet Gynecol 1999;93:265-270.

28 Panet-Raymond V, Gottlieb B, Beitel LK, Pinsky L, Trifiro MA: Interactions between androgen and estrogen receptors and the effects on their transactivational properties. Mol Cell Endocrinol 2000;167:139-150. 